\title{
Curriculum Development: Complexity and Challenges in Shaping the Future
}

\author{
Murray Print \\ University of Sydney, Australia
}

\section{How to cite}

Print, M. (2018). Curriculum Development: Complexity and Challenges in Shaping the Future. Asia Pacific Journal on Curriculum Studies, 1(1), 7-13. https://doi.org/10.53420/apjcs.2018.2

\begin{abstract}
All educational enterprises use a curriculum that must be designed and developed by one person or group and immediately, issues of complexity and challenge arise. From an outsider viewpoint curriculum development appears simple and straightforward, but it is not what it appears. Rather, it is complex, full of twists and turns, and requiring significant thought and input from curriculum developers. This article identifies and investigates significant influences on the process of curriculum development and locates these in the context of developing a component of the recently completed Australian Curriculum.
\end{abstract}

Keywords: curriculum development, Australian Curriculum

\section{Introduction}

All educational enterprises use a curriculum even if they do not formally acknowledge a curriculum in their training program. Consequently, any curriculum must be designed and developed by one person or group and immediately, issues of complexity and challenge arise. Who designs and develops a curriculum and what do they bring with them to the development task?

All education or training programs require a curriculum as it provides the guide for what students will learn. This is usually understood as a document to guide teachers/ educators in their delivery to students. The curriculum is devised and developed usually by a group or possibly one person such as a teacher for one's class. Who are these curriculum developers? Who develops the curriculum in large measure determines what it will be like and its potential impact on students. These preliminary concepts and questions reveal that the development of, indeed the very understanding of, curriculum is complex and problematic.

\section{Curriculum Complexity}

Curriculum quality is highly variable and is significantly influenced by its developers, but before a curriculum can be produced, we should pose several key questions.

Two key questions that reveal the complexity of curriculum:

1. What is curriculum?

2. Who develops curriculum?

\section{What is curriculum?}

A curriculum is the totality of the learning experience of students under the auspices of the learning organization. Although definitions of curriculum vary considerably such that a consensus definition appears all but impossible, I have argued for some time that curriculum may be defined as "all the planned learning opportunities offered by the organization [such as a school] to learners and the experiences learners encounter when the curriculum is implemented" (Print, 1993, p. 9). Although for most of our experience and research this organization will be a school, it could also be a university, a pilot training organization, a technical college, and any other form of educational training.

This broad definition of curriculum in the context of schools includes the formal curriculum (school subjects), the informal curriculum (other planned learning experiences that are not subjects such as school assemblies; charity fundraising), and the extra-curriculum (learning experiences outside of school hours). Meanwhile, although significant, perhaps very significant, the 
hidden curriculum (unintended learning by students that was not planned for them) is not part of this definition as, by its very nature, it was not planned.

We usually think of curriculum as a document to guide learners in achieving their goal. In the context of schools, a curriculum is often called a syllabus: a broad-based set of learning experiences for students that includes acquiring literacy, numeracy, science, history, social science such as geography and economics, physical health as well as sports, music, arts, and foreign languages.

However, the term 'curriculum' is often employed in different ways leading to possible confusion. Curriculum is, in effect, whatever people say it is - a group of school subjects, the written syllabus of subject matter content, learner experience, or even teacher practice in classrooms. Another way of viewing the term is to think of it as it is applied. For example:

1. Intended curriculum (Policy and document on what students should learn)

2. Implemented curriculum (What is taught by teachers in classrooms)

3. Achieved curriculum (What students actually learn as measured in some way - but how to determine/measure student learning in meaningful ways?)

4. Where does the curriculum come from?

Curriculum development. This is the process of planning, constructing, implementing, and evaluating learning opportunities intended to produce desired changes in learners, i.e., transforming curriculum conceptions and needs into a curriculum document and its application in an educational context.

This process can be achieved in a variety of ways as long as all four components of curriculum development are included. One model is found in Print's (1993) Curriculum Design and Development, which can be applied to a variety of contexts from schools to education systems.

The Australian Curriculum, Assessment and Reporting Authority (ACARA) employs the same curriculum development process though it uses different terminology:

Phase 1: Curriculum Shaping (planning)

Phase 2: Curriculum Writing (constructing)

Phase 3: Implementation (implementing)

Phase 4: Curriculum Evaluation and Review (evaluating)

These four phases (ACARA, 2012) follow the more detailed components in my curriculum model: Organization (Presage); Development; Application (Print, 1993, pp. 81-88).

\section{Curriculum design}

This is the arrangement of the elements of curriculum (intent, content, pedagogy, assessment) into a desired structure/pattern over time. It uses the design forces of horizontal organization (what should be learnt and the arrangement of that learning in a period of time such as a term, semester, or year) and vertical organization (what should be learnt and the sequential arrangement of that learning over a period of time such as the years of elementary school or high school).

Most school curricula are dominated by subject-centred designs where students experience a number of school-level subjects, such as history or English (usually older students), or learner-centred designs which may be play-based, experiential learning, or problem-solving (younger students).

What is important in the design and development of any curriculum is to know before commencement what is wanted from that curriculum in terms of student outcomes. In the broadest, should the school curriculum aim to educate democratic citizens, efficient workers, 'good' people, skilled technicians, or enlightened individuals? This overall aim then leads to further questions:

1. What form should the curriculum take? (What approach to achieve the aim?)

2. What outcomes to expect from this curriculum? (Identify the knowledge and skills of participants in curriculum, perhaps values and attitudes as well.)

When these questions are addressed, then decide who will develop the specific curricula. 
Who develops curricula? Before we know what the curriculum will be about and we can develop and design such a curriculum, a key question must be posed: who makes the decisions on whom to include in a curriculum development team? Who will be included or excluded? These are central to understanding the final product as these curricula are clearly influenced by the nature of the team that develops them (Print, 1993).

In the case of the Australian Curriculum Civics \& Citizenship (ACCC), the senior administrators decided. With their assistance, it was then left to me to determine which persons would be included or excluded from the curriculum team to develop the ACCC. In making these decisions it is essential to recognize that the persons who develop a curriculum determines, in large measure, the final product and consequently should not to be underestimated. Experience shows that participants may frequently not be experienced in the study of curriculum, are often subject specialists who know a specific content area, may be political appointees, present difficulties for maintaining an inclusive/exclusive balance, and need to maintain limited numbers or the task may become unmanageable.

\section{Curriculum Development Challenges}

Curriculum development is a complex, time-consuming process fraught with many challenges. Some of the key challenges influencing curriculum development especially for schools are political intervention, educational theories, conflicted stakeholders, and who is included/excluded in the curriculum development process as discussed previously.

\section{Political ideology challenges}

Curricula are not politically free as they are invariably developed in a political context of some form or influenced by political decision-makers such as politicians. The prevailing political ideology dominating the West for the past few decades is neoliberalism. Its dominance reflects the ability of the wealthy to assert their power to restructure society and government for their benefit. They have transformed the political decision-making process to one where private interests influence the political process through various means.

Here, education is seen as a commodity. Market ideas of scarcity, access, competition, and profit dictate or dominate education policy. However, research shows that neoliberal ideas of individual freedom and autonomy (i.e., choice), coupled with a belief in market forces to 'fix' education and provide social mobility, have contributed to ever-increasing inequality. Neoliberalism has had many consequences for education and school curricula, which has resulted in increasing challenges for curriculum developers.

Some examples include:

1. Increasing privatization of education from preschool to university

2. Growing inequality in student education outcomes

3. Pressure for greater vocation emphasis, especially employable skills

4. Education is seen as an investment, which in turn has contributed to greater emphasis on school fees and payment for curriculum extras such as sports and music

5. Greater emphasis on school choice within both government education systems and non-government education, e.g., the vouchers approach produces more similar social/economic groups and consequently, less integration amongst these groups.

\section{Educational theories challenges}

Curriculum development is often affected by prevailing educational theories that are influential from time to time. These educational theories may also be in opposition to each other therefore raising further challenges to curriculum developers. One of the earliest theories to influence curriculum was the work of John Dewey. His theoretical writings on experiential learning and democracy (Dewey, 1916) have been significant for a century, reinterpreted by later generations in their own contexts.

The process of curriculum development was influenced by many educational theorists over the twentieth century including Ralph Tyler (Print, 1993) and Hilda Taba (Print, 1993) through what were known as the objectives or rational models of curriculum development. These were subsequently reconceptualized and expanded by curriculum developers such as Skilbeck (1984) and Print (1993).

Similarly, educational psychologists such as Benjamin Bloom (Print, 1993) and Jerome Bruner (Print, 1993) affected how curriculum was conceptualized and presented. Bruner's work in the 1960s-1980s, for example, through engaged curriculum projects affected how we thought about and engaged curricula with students. Bloom's taxonomy and his approach to formative 
and summative evaluation were significantly influential during this period as well. Subsequently, however, their influence over curriculum has diminished.

\section{Conflicting stakeholders}

The development of any curriculum is likely to involve multiple stakeholders. The development of school curricula is an example of engagement with multiple stakeholders, many who frequently display conflicting positions on curriculum as Michael Apple (1993) demonstrated. For example, in early childhood education a conflict has emerged between stakeholders who support playbased learning compared with those who advocate greater structured learning. This situation presents a problem for curriculum developers unless a resolution can be found.

Curriculum development may also be influenced by other groups of stakeholders that may be in conflict. In Australia, tension exists between stakeholders who support government schools compared with those who advocate non-government schooling. This is evident when government schools account for around $65 \%$ of all students, Catholic Education about $21 \%$, and Independent Schools around $14 \%$ of all students.

Other groups with stakeholder interests in the curriculum process can include state-based curriculum authorities, universities, schools and teachers, parents and parent lobby groups, religious groups, and even NGOs such as Red Cross and Greenpeace that seek to influence the content of school curricula (Print, 1993).

\section{Australian Curriculum Civics and Citizenship (ACCC)}

The Australian Curriculum, Assessment and Reporting Authority has responsibility for engaging stakeholders with the Australian Curriculum. Curriculum development is seen as a shared task, a joint experience of many, with key writers. This encourages a critical perspective in the development process. The preparation of the Australian Curriculum Civics and Citizenship (ACARA, 2014, 2016) is an example of the curriculum development process in operation as well as the complexity and challenges faced by curriculum developers.

In the past quarter century, Civics and Citizenship Education (CCE) in Australian education has emerged as a significant component of Australian school education as it has sought to underpin and strengthen Australia's democratic way of life (Print, 2007, 2008). The term Civics and Citizenship Education is used in Australia, rather than civic education, though the terms overlap considerably in terms of school curriculum content. By CCE, it means that the school subject or learning experience prepares school students in a democracy to become an active, informed citizen. As identified in the recently developed Australian Curriculum:

Civics and Citizenship provides opportunities to develop students' knowledge and understanding of Australia's representative democracy and the key institutions, processes, and role people play in Australia's political and legal systems. Emphasis is placed on Australia's federal system of government, derived from the Westminster system, and the liberal democratic values that underpin it such as freedom, equality and the rule of law. The curriculum explores how the people, as citizens, choose their governments; how the system safeguards democracy by vesting people with civic rights and responsibilities; how laws and the legal system protect people's rights; and how individuals and groups can influence civic life. (ACARA, 2014, p. 4)

In 2011 Professor Murray Print was invited to prepare a background discussion paper on what CCE should look like in a national curriculum. This was well received and Professor Print, as Lead Writer, together with an advisory group, was then asked to prepare a more substantial Shape Paper for public review. This was widely distributed, reviewed, and received feedback including through a national forum in 2012. As Lead Writer and then Team Leader with an advisory group and writers for primary and secondary schools, Professor Print then produced the Australian Curriculum Civics and Citizenship (ACCC) which was subsequently distributed, reviewed, received feedback, and finalized by the end of 2013 (ACARA, 2014).

The influential Shape Paper (ACARA, 2012) had set the scene for what would be included in the final curriculum document. It was clear that Civics and Citizenship should be part of the formal school curriculum, though initially restricted to Years 3-10 as well as in wider whole-school programs: "this could include participation in experiences external to the school but linked to the school curriculum (for example, community activities, parliamentary education programs, civic institution visits and electoral commission programs)" (ACARA, 2012, p. 15). 
By the time of writing the curriculum in 2013, it was evident that while knowledge and understanding of the nation, its government, its legal system, and institutions were a key component of the formal curriculum, so too was community-based learning experiences.

Curriculum development should be transparent at key stages and this principle was applied to the development of the ACCC. Shape Paper as a formative curriculum document, for example, was given a three-month period for public response, comments from which were incorporated into the revised version. This process reflected the competing visions of stakeholders as to what should constitute the ACCC.

Guided by the influential Melbourne Declaration (Ministerial Council on Education, Employment, Training and Youth Affairs [MCEETYA], 2008) the ACCC curriculum aims to reinforce students' appreciation and understanding of what it means to be a citizen. It explores ways in which students can actively shape their lives, value their belonging in a diverse and dynamic society, and positively contribute locally, nationally, regionally, and globally. As reflective, active, and informed decision- makers, students should be well placed to contribute to an evolving and healthy democracy that fosters the wellbeing of Australia as a democratic nation. More specifically, the ACCC aims to ensure that students develop:

1. a lifelong sense of belonging to and engagement with civic life as an active and informed Australian citizen in a secular democratic nation with a dynamic, multicultural and multi-faith society

2. knowledge, understanding and appreciation of the values, principles, institutions and practices of Australia's system of democratic government and law, and the role of the citizen in Australian government and society

3. skills - including questioning and research; analysis, synthesis and interpretation; problem solving and decision making; communication and reflection - to investigate contemporary civics and citizenship, and foster responsible participation in Australia's democracy

4. capacities and dispositions to participate in the civic life of their nation at a local, regional and global level. (ACARA, 2014)

In addition the $\mathrm{ACCC}$ seeks to enhance student understanding and application of liberal democratic values such as freedom of expression, association, religion, rights and responsibilities, equity, intercultural understanding, sustainability, democratic identity, and global citizenship.

To achieve these goals the ACCC consists of three key themes based around the major goal of building and sustaining Australian democracy:

1. Government and democracy involves a study of Australian democracy and the key institutions, processes and roles people play in Australia's system of government.

2. Laws and citizens examines Australia's legal system, the creation of laws and the rights and legal obligations of Australian citizens.

3. Citizenship, diversity and identity explores the shared values of Australian citizenship, Judeo-Christian traditions, the diversity of Australia as a multicultural and multi-faith society, and what shapes identity. (ACARA, 2014, p. 5)

Within each of these key themes, content was identified in terms of knowledge, skills, and values. While knowledge and skills were clearly stated at each age level from Years 3-10, identification of values was across all years of schooling. In this context, the Australian Curriculum Civics and Citizenship emphasized values such as dialogue, participation, tolerance, respect, and democratic practices in society.

Before the ACCC could be officially endorsed for application in schools, however, a politically inspired review conducted in 2104 recommended several changes (Australian Government, 2014). Surprisingly, most of the review recommendations were politely and conveniently ignored by the federal government in its response. Although, the government did respond to pressure for less subject matter content and other changes in the ACCC including an increased emphasis on the Australian Constitution (Australian Government, 2014). As the Australian Government was experiencing severe public backlash to many elements of its broader educational program at the time, such as the proposed fee deregulation for universities, it was now politically expedient for the finally approved Australian Curriculum to diminish the rhetoric of the previously politically inspired review (Print, 2016). The main changes adopted for CCE by the Education Council included the integration of the subjects History, Geography, Civics and Citizenship, and Business into a single entity called Humanities and Social Sciences (HASS) for the primary school years, as well as greater emphasis on the origins of the Australian system of government including its constitution.

The Australian Curriculum: Civics and Citizenship (ACCC) was finally endorsed by the Education Council, the meeting of all Australian Ministers of Education, in September 2015. The ACCC 2013 version had previously been supported by all state and 
territory governments throughout its development process and agreed for use in their schools subject to individual state adjustments. However, the politically inspired review demonstrated that curriculum can be affected by current political ideologies as was this case of politically conservative views. Consequently, although ACARA had released the 2013 Australian Curriculum: Civics and Citizenship v7.2 version for use by education systems and schools from 2014 (ACARA, 2014), this version has now been replaced with the later modified v8 (ACARA, 2016).

\section{Challenges}

As with any curriculum developed for schools, there are several challenges facing the implementation of the ACCC in all of Australia's 9,450 primary and secondary schools. Many of these challenges reflect Australia's federal political system where the states or jurisdictions have constitutional power over education. The most significant challenge is the timeline and nature of implementation that differs somewhat according to the different jurisdictions. For example, New South Wales, Australia's most populous state, was the only jurisdiction not to have started or planned to commence implementation of the ACCC by the end of 2015. Meanwhile, to complicate matters, some states had commenced implementing the v7.2 version while others planned to implement the post-review 2015 v8 version. Victoria developed its own curriculum using the Australian Curriculum merely as an informing document.

Second, and importantly for any newly implemented curriculum, teachers continue to require extensive professional development to implement the ACCC effectively, and this has not been forthcoming. Third, limited teaching resources are available for the ACCC with responsibility for provision vested with the jurisdictions, sectors, schools, and teachers. Fourth, the next generation of teachers will require teacher education programs that reflect the ACCC as it is implemented within the Australian jurisdictions. Fifth, how Australian schools will integrate ACCC into growing initiatives in global citizenship is another challenge. Finally, how the ACCC, and CCE more generally, can engage more young Australians to become active, informed citizens is a long term challenge. Despite these challenges, the implementation of the ACCC will continue albeit slowly.

\section{References}

Apple, M. (1993). The politics of official knowledge. New York: Routledge.

Australian Curriculum, Assessment and Reporting Authority. (2012). The shape of the Australian curriculum: Civics and Citizenship. Sydney: ACARA.

Australian Curriculum, Assessment and Reporting Authority. (2014). The shape of the Australian curriculum: Civics and Citizenship. Sydney: ACARA.

Australian Curriculum, Assessment and Reporting Authority. (2016). The Australian curriculum v8 Civics and Citizenship. Sydney: ACARA.

Australian Government. (2014). Review of the Australian curriculum. Canberra: Department of Education.

Dewey, J. (1916). Democracy and education: An introduction to the philosophy of education. New York: MacMillan.

Ministerial Council on Education, Employment, Training and Youth Affairs. (2008). Melbourne declaration on educational goals for young Australians. Canberra: MCEETYA.

Print, M. (1993). Curriculum development and design (2nd ed.). Sydney: Allen \& Unwin.

Print, M. (2007). Citizenship education and youth participation in democracy. British Journal of Educational Studies, 55(3), 325345.

Print, M. (2008). Education for democratic citizenship in Australia. In J. Arthur, I. Davies, \& C. Hahn (Eds.), The Sage Handbook of education for citizenship and democracy, pp. 95-108. London: Sage Publications Ltd.

Print, M. (2016). The recent history of teaching Civics and Citizenship education in Australia. In A. Peterson \& L. Tudball (Eds.), Civics and Citizenship education in Australia: Challenges, practices and international perspectives, pp. 7-22. London: Bloomsbury. 
Skilbeck, M. (1984). School-based curriculum development. London: Harper \& Row. 